\title{
ANALISIS FAKTOR-FAKTOR YANG MEMPENGARUHI PERHITUNGAN PPH BADAN PADA PERUSAHAAN PEMBIAYAAN DI PT. HASJRAT MULTIFINANCE MANADO
}

\author{
Allbrian J. W. Rantung ${ }^{1}$, David P.E Saerang ${ }^{2}$, Winston Pontoh ${ }^{3}$ \\ 1,2,3 Jurusan Akuntansi, Fakultas Ekonomi dan Bisnis, Universitas Sam Ratulangi, Jl. Kampus Bahu, Manado, \\ 95115, Indonesia
}

E-mail :allbrianrantung@yahoo.co.id

\begin{abstract}
One of the largest sources of state revenue in the tax sector is bandan income tax / PPh 29. This study aims to determine what factors influence the calculation of corporate income tax on finance companies at PT. Hasjrat Multifinance Manado. This research uses descriptive method which is used to find out how many factors influence the calculation of corporate income tax.From the results of the study it is known that there are several factors that influence the calculation of corporate income tax, namely the factor of sales contribution on credit by the dealer, the interest rate factor and the administrative revenue factor. The results of this study indicate that these factors are the main source of income for finance companies, thus affecting the calculation of Corporate Income Tax. The greater the contribution of the dealer will affect the value of financing, and the value of financing will affect the value of revenue and revenue of the company so that automatically the greater the contribution of corporate income tax/PPh 29.
\end{abstract}

Keywords :Financing contributions, installments and interest income, taxes.

\section{PENDAHULUAN}

Setiap perusahaan wajib menghitung, menyetor, dan melaporkan semua kewajiban perpajakan sendiri atau disebut self assestment. Hal ini dapat terlaksana dengan baik jika Perusahaan pembiayaan dapat memahami peraturan perpajakan mengenai Pajak penghasilan badan (PPh badan), faktor-foktor yang mempengaruhi perhitungan PPh badan dan mengikuti aturan yang berlaku sesuai dengan undang-undang perpajakan. Pajak merupakan salah satu sumber penerimaan negara, dan masyarakat dapat berpartisipasi secara aktif dalam pembiayaan pembangunandengan melalui kesadaran pembayaran pajak, karena pembayaran pajak merupakan perwujutan pengabdian dan peran serta setiap warga negara dalam membiayai keperluan pembangunan nasional. Salah satu penerimaan terbesar di sektor pajak antara lain yaitu pajak penghasilan, perhitungan pajak penghasilan badan ( $\mathrm{PPh}$ badan) sebetulnya dilakukan oleh wajib pajak badansendiri dalam SPT pajak penghasilan. Dalam undang-undang pajak penghasilan $(\mathrm{PPh})$ mengatur pajak atas penghasilan yang diterima atau di peroleh wajib pajak badan. Undang-undang PPh ini juga mengatur subjek pajak, objek pajak, serta cara menghitung dan cara melunasi pajak yang terutang serta juga akan memberikan kemudahan bagi wajib pajak badan dalam melaksanakan kewajiban perpajakan, hal ini diataur dalam UU no.16 Tahun 2000 tentang ketentuan umum dan tata cara perpajakan. Pada umumnya penjualan kendaraan atau barang secara kredit yang dilakukan oleh dealer, dibutuhkan suatu lembaga pembiayaan untuk membiayaipermintaan konsumen dengan pembelian secara kredit tersebut.PT. Hasjrat Multifinance adalah salah satu perusahaan pembiayaan dapat memfasilitasi kebutuhan konsumen untuk medapatkan kendaraan atau barang yang diinginkan dengan pembayaran secara angsur.

Dalam kegiatan usahanya, PT. Hasjrat Multifinance melakukankegiatan pembiayaan untuk pengadaan barang dan/atau jasa dengan sesuai yang di atur dalam peraturan Otoritas 
Jasa Keuangan (POJK) no. 29/POJK.05/2014 tentang Penyelenggara usaha perusahaan pembiayaan, yang meliputi; Pembiayaan Investasi, Pembiayaan Modal Kerja, Pembiayaan Multiguna, dan Kegiatan usaha pembiayaan lain yang disetujui oleh Otoritas Jasa Keuangan (OJK). Dengan adanya lembaga pembiayaan ini maka Delaer dengan sendirinya dapat meningkatkan volume penjualannya dan dengan sendirinya kontribusi perusahaan pembiayaan dapat meningkatkan juga transaksi pembiayaannya. Dengan meningkatnya penjualan di dealer melalaui perusahaan pembiayaan, maka mempengaruhi juga pendapatan perusahaan sebagai salah satu faktor perhitungan $\mathrm{PPh}$ badan. Dengan adanya fasilitas pembiayaan yang diberikan kepada konsumen maka dapat mempermudah konsumen untuk mendapatkan kendaraan atau barang yang di inginkan,karena pembayaran di lakukan secara angsur sesui perjanjian yang sudah di sepakati oleh perusahaanpembiayaan dan konsumen, dan perusahaan pembiayaan akan mencatan sebagai piutang pembiayaan, piutang timbul ketika perusahaan melakukan transaksi pembiayaan.

\section{TINJAUAN PUSTAKA}

Definisi Akuntansi. Akuntansi meliputi seluruh proses pelaporan, mulai dari pengidentifikasian transaksi bisnis, pencatatan, perkomunikasian (dalam bentuk laporan), sampai pada tahapan analisis dan interpretasi (Hery, 2013:8).

Definisi Pajak. Pajak dianggap sebagai suatu kewajiban menyerahkan sebagian harta kekayaan ke kas negara disebabkan suatu keadaan, kejadian dan perbuatan yang memberikan kedudukan tertentu tetapi bukan suatu hukuman menurut peraturan yang ditetapkan pemerintah serta dapat dipaksakan tetapi tidak ada jasa timbal balik dari negara secara langsung untuk memelihara kesejahteraan umum.(Brotodiharjo (1993:2).

Akuntansi Pajak. Akuntansi pajak adalah suatu proses pencatatan, penggolongan dan pengikhtisaran suatu transaksi keuangan kaitannya dengan kewajiban perpajakan san diakhiri dengan pembuatan laporan keuangan fiskal sesuai dengan ketentuan dan peraturan perpajakan yang terkait sebagai dasar pembuatan Surat Pemberitahuan Tahunan (Supriyanto, 2011:2).

Fungsi Pajak. Menurut Resmi (2010:1) terdapat dua fungsi pajak yaitu:

1. Pajak berfungsi sebagai sumber penerimaan negara, sebagai pembiayaanpengeluaran rutin maupun untuk pembangunan;

2. Dan pajak sebagai pengatur, melaksanakan suatu kebijakan pemerintah dalam bidang sosial dan ekonomi agar lebiih makmur dan sejahtera.

Jenis-jenis Pajak. Menurut Resmi (2013:) Pengelompokan pajakterdiri atas pengelompokan menurut golongan, pengelompokan menurut sifat, dan pengelompokan menurt lembaga pemungut.

1. Berdasarkan Golongan terdiri atas: (a). Pajak langsung (Direct Tax); dan (b) Pajak tidak langsung (Indirect Tax).

2. Berdasarkan sifatnya pajak terdiri atas: (a) Pajak subjektif; dan (b) Pajak objektif.

3. Berdasarkan lembaga pemungut: (a) Pajak Negara (Pajak Pusat); dan (b) Pajak Daerah.

Tarif Pajak. Tarif pajak menurut Mardiasmo (2016:10) terdiri dari 4 macam :

1. Tarif sebading/proporsional. Tarif berupa presentase yang tetap, terhadap berapapun jumlah yang dikenai pajak sehingga besarannya pajak yang terutang proporsional terhadap besarnya nilai yang dikenai pajak.

2. Tarif tetap. Tarif berupa jumlah yang tetap (sama) terhadap berapapun jumlah yang dikenakan pajak sehingga besarannya pajak yag terutang tetap.

3. Tarif progresif. Presentase tarif yang digunakan semakin besar bila jumlah yang dikenakan pajak semakin besar.

4. Tarif degresif. Presentase tarif yang digunakan semakin kecil bila jumlah yang dikenai pajak semakin besar. 


\section{Konsep Wajib Pajak}

Pengertian Wajib Pajak. Wajib Pajak adalah orang pribadi ataupun badan, meliputi pembayaran pajak, pemotongan pajak, dan pemungutan pajak yang memiliki hak dan kewajiban perpajakan sesuai dengan ketentuan perundang-undangan perpajakan.(Mardiasmo, 2016:27).

Wajib Pajak badan. Menurut undang-undang Perpajakan 2008, badan adalah sekumpulan orang dan/atau modal yang merupakan kesatuan baik yang melakukan usaha maupun yang tidak melakukan usaha yang meliputi perseroan terbatas, perseroan komanditer, perseroan lainnya, badan usaha miliknegara atau badan usaha milik daerah dengan nama dan dalam bentuk apapun, firma, kongsi, koperasi, dana pensiun, persekutuan, perkumpulan,yayasan, organisasi massa, organisasi sosial politik, atau organisasilainnya, lembaga, dan bentuk badan lainnya termasuk kontrak investasi kolektif dan bentuk usaha tetap.

\section{Konsep Pajak Penghasilan}

Pengertian Pajak Penghasilan. Pengertian pajak penghasilan menurut Resmi (2008):

"Pajak penghasilan adalah suatu kontribusi yang diwajibkan kepada negara yangterutang oleh orang pribadi atau badan atas setiap tambahan kemampuan ekonomisyang diterima wajib pajak dalam negeri yang dapat dipakai konsumsi ataumenambah kekayaan wajib pajak dengan nama dan bentuk apapun dengan merujukpada undang-undang pajak penghasilan sebagimana telah diubah beberapa kali danterakhir dengan UU nomor 36 tahun 2008".

Definisi Wajib Pajak Badan / PPh 29. Menurut UU 36 tahun 2008, Pajak penghasilan pasal 29 (PPh 29) adalahPPh kurang bayar (KB) yang tercantum dalam SPT tahunan, yaitu sisa dari PPh yang terutang dalam tahun pajak yang bersangkutan dikurangi dengan kredit $\mathrm{PPh}$ ( $\mathrm{PPh}$ pasal 21,22,23 dan 24) dan PPh pasal 25. Jika terdapat PPh kurang bayar, wajub pajak (WP) berkewajiban untuk melunasi kekurangan dari pembayaran pajak yang terutang sebelum dikeluarkannya SPT pajak penghasilan. Jika tahun buku sama dengan tahun kalender, kekurangan dari pajak tersebut harus sudah dilunasi paling lambat 31 Maret untuk wajib pajak orang pribadi atau 30 April untuk wajib pajak badan (WPB) sesudah tahun pajak berakhir.

\section{Konsep perusahaan pembiayaan}

Pengertian perusahaan pembiayaan. Perusahaan pembiayaan berperan penting dalam pendistribusian dan pengalokasian sumber daya keuangan kepada pelaku usaha dan masyarakat Indonesia, baik melalui penyediaaan pembiayaan atas barang-barang produktif yang dibutuhkan oleh pelaku usaha maupun barang-barang konsuntif yang menjadi kebutuhan masyarakat, yang pada akhirmya akan mendorong terjadinya peningkatan aktivitas ekonomi dalam masyrakat. Dengan terwujutnya perusahaan pembiayaan yang tangguh, kontributif, inklusif, juga dapat berkontribusi untuk menjaga sistem keuangan yang stabil dan berkelanjutan. Dalam rangka meningkatkan industry perusahaan pembiayaan, perlu adanya terobosan-terobosan strategis yang dapat memperluas alternatif kegiatan usaha untuk meningkatkan penerimaan pajak oleh perusahaan pembiayaan dan memberi ketersediaan bagi masyrakat yang masih menghadapi keterbatasan akses dalam pembiayaan(Ahamd Husain: 2018:1).

Menurut undang-undang nomor 21 tahun 2011 tentang Otoritas Jasa Keuangan. Lembaga pembiayaan adalah badan usaha yang melakukan kegiatan pembiayaan dalam bentuk penyediaan dana atau barang modal sebagaiamana yang dimaksud dalam peraturan perundang-undang mengenai lembaga pembiayaan.Pembiayaan adalah jasakeuangan yang diberikan oleh perusahaan pembiayaan untuk pengadaan barang dan/ atau jasa. Jenis barang yang di bayai misalnya kendaraan bermotor, barang-barang elektronik, alat-alat rumah tangga, rumah dan pabrik. Untuk jenis jasa yang di biayai misalnya jasa penyelenggara pendidikan, jasa agen perjalanan, jasa rumah sakit, dan jasa professional seperti arsitek. 
Dalam Modul Asosiasi Perusahaan Pembiayaan Indonesia 2016. Perusahaan pembiayaan adalah badan usaha yang melakukan kegiatan pembiayaan untuk pengadaan barang dan/atau jasa. Jenis barang yang di biayai misalnya kendaraan bermotor, alat-alat rumah tangga, barang-barang elektronik, rumah dan pabrik. Jenis jasa yang di biayai misalnya jasa penyelenggara pendidikan, jasa agen perjalanan, jasa rumah sakit, dan jasa professional seperti arsitek.

Kegiatan usaha perusahaan pembiayaan menurut Perturan Otoritas Jasa Keuangan no. 29 tahun 2014 terdiri dari :

1. Pembiayaan Investasi. Pembiyaan investasi yaitu pembiayaan untuk pengadaan barangbarang modal beserta jasa yang diperlukan untuk aktivitas usaha/investasi, rehabilitasi, modernisasi, ekspansi atau relokasi tempat usaha/investasi yang diberikan kepada Debitur dalam jangka waktu lebih dari 2 (dua) tahun (Pasal 1 angka 1POJK no. 29 2014. Debitur dalam hal ini badan usaha atau perserongan yang memiliki usaha produktif dan atau, memiliki ide-ide untuk pengembangan usaha produktif.

2. Pembiayaan Modal Kerja. Pembiayaan modal kerja merupakan pembiayaan untuk memenuhi kebutuhan pengeluaran-pengeluaran yang habis dalam satu siklus aktivitas usaha debitur dan merupakan pembiayaan dengan jangka waktu paling lama 2 (dua) tahun. Dalam hal ini customer harus memiliki usaha produktif dan memiliki ide-ide untuk pengembangan usaha produktif.

3. Pembiayaan Multiguna. Pembiayaan multiguna adalah pembiayaan untuk pengadaan barang atau jasa yang diperlukan oleh debitur untuk pemakaian / konsumsi dan bukan untuk keperluan usaha aktifitas produktif dalam jangka waktu yang diperjanjikan. Dalam hal ini customer harus memiliki tujuan yang jelas. Contoh pembiayaanmultiguna adalah: pembiayaan mobil, sepeda motor, elektronik, dan sebagainya.

4. Kegiatan usaha pembiayaan lain yang disetujui oleh Otoritas Jasa Keuangan. Setelah terlebih dahulu mendapat persetujuan dari OJK serta memiliki tingkat kesehatan keuangan minimum sehat dan tidak sedang dikenakan sanksi oleh Otoritas Jasa Keuangan (OJK) . Cara pembiayaan lain, wajib mengajukan permohonan terhadap OJK dengan melampirkan dokumen yang berisi uraian minimal : Produkyang akan dipasarkan, analisis produk usaha, mekaniisme/cara pembayaran yang akan dilakukan, hak dan kewajiban para pihak.

Skema / cara pembiayaan. Dalam usaha kegiatan pembiayaan, skema / cara bayar terdiri dari:

1. Sewa pembiayaan ( Finance lease)

Adalah kegiatan pembiayaan dalam bentuk penyediaan barang oleh perusahaan pembiayaan untuk digunakan debitur selama jangka waktu tertentu yang mengalihkan secara substansial manfaat dan risiko atas barang yang dibayar.

Catatan atas cara pembiayaan ini adalah:

- Kepemilikan atas barang objek transaksi sewa pembiayaan berada pada perusahaan pembiayaan.

- Debitur dilarang menyewa-pembiayaankan kembali barang yang disewa pembiayaan kepada pihak lain.

- Perusahaan pembiayaan wajib menempelkan plakat atau etiket pada barang yang disewa pembiayaan.

- Digunakan dalam kegiatan usaha pembiayaan investasi dan pembiayaan multiguna.

2. Jual dan sewa balik (sale and leaseback)

Adalah kegiatan pembiayaan dalam bentuk penjualan suatu barang oleh debitur kepadaperusahaanpembiayaan yang disertaimenyewakembalibarang tersebut kepada debitur yang sama.

Catatan atas cara pembiayaan ini adalah: 
- Kepemilikan atas barang objek transaksi jual dan sewa balik berada pada perusahaan pembiayaan.

- Debitur adalah badan usaha atau perorangan yang memiliki usaha produktif dan atau ide-ide untuk pengembangan usaha produktif.

- Digunakan dalam kegiatan Pembiayaan Investasi dan Pembiayaan Modal Kerja.

3. Anjak piutang (Factoring)

Adalah kegistan pembiayaan dalam bentuk pembelian piutang usaha suatu perusahaan berikut pengurusan atas piutang tersebut.

- Anjak piutang dengan pemberian jaminan dari penjual piutang (Factoring with Recourse) adalah transaksi anjak piutang usaha dimana penjual piutang menanggung resiko tidak tertagihnya sebagian atau seluruh piutang yang dijual kepada perusahaan pembiayaan.

- Anjak piutang tanpa pemberi jaminan dari penjual piutang (factoring without Recourse) adalah transaksi anjak piutang usaha dimana perusahaan pembiayaan menanggung resiko tidak tertagihnya seluruh piutang yang dijual kepada perusahaan pembiayaan.

- Digunakan dalam kegiatan Pembiayaan Investasi dan Pembiayaan Modal Kerja.

- Pembelian dengan pembayaran secara angsuran

4. Pembelian dengan pembayaran secara angsuran

Pembelian dengan pembayaran secara angsuran adalah kegiatan pembiayaan dalam bentuk pengadaan barang atau jasa yang dibeli oleh Debitur dari penyedia barang atau jasa dengan pembayaran secara angsuran. Pembelian dengan pembayaran secara angsur(Installment financing) dapat digunakan untuk pembiayaan Investasi dan pembiayaan multiguna.Installment financing untuk barang adalah digunakan untuk pembiayaan pengadaaan barang yang diperlukan oleh debitur untuk kegiatan selain investasi/modal kerja dengan kepemilikan barang berada di debitur. Contohnya seoarang debitur membutuhkan pembiayaan mobil.Installment financing jasa digunakan untuk debitur yang memiliki kebutuhan pembiayaan jasa, dimana perusahaan pembiayaan dibayarkan langsung oleh perusahaan pembiaaan kepada penyedia jasa. Misalnya seorang debitur membutuhkan pembiayaan untuk sekolah S2.

5. Pembiayaan proyek (Project financing)

Pembiayaan proyek adalah pembiayaan yang diberikan dalam rangka pelaksanaan sebuah proyek yang memerlukan pengadaan beberapa jenis barang modal dan/atau jasa yang terkait dengan pelaksanaan pengadaan proyek tersebut.Pembiayaan proyek dapat digunakan pada pembiayaan investasi, seperti misalnya pembangunan pabrik, perluasan gudang, renovasi gedung kantor.

6. Pembiayaan Infrastruktur

Pembiayaan infrastruktur adalah pembiayaan dalam bentuk pengadaan barang dan/atau jasa untuk pembangunan infrastruktur. Perusahaan pembiayaan wajib: (1) memiliki tingkat kesehatan keuangan dengan kondisi minimum sehat; (2) memiliki ekuitas lebih besar dari Rp.1T; dan (3) memiliki SOP terkait pembiayaan infrastruktur. Pembiayaan infrastruktur dapat dilakukan dengan menggunakan satu atau dua lebih cara pembiayaan: (a) sewa pembiayaan; (b) jual dan sewa balik; (c) anjak piutang dengan pemberian jaminan dari penjual piutang; dan (d) pembelian dengan pembayaran secara angsuran.

7. Fasilitas modal usaha

Fasiltas modal usaha adalahpembiayaan modal kerja yang dibayarkan langsung oleh perusahaan pembiayaan kepada penyedia barang atau jasa. Perusahaan pembiayaan dalam hal ini dilarang memberikan dana tunai kepada debitur. Dana diberikan kepada penyedia barang atau jasa, bukan Debitur. Wajib dilakukan dengan memberikan pembiayaan 
berdasarkan bukti tagihan pembelian barang atau penggunaan jasa yang diterima Debitur dari penyedia barang atau jasa.

\section{METODE PENELITIAN}

Jenis Penelitian. Jenis penelitian ini adalah penelitian kualitatif dengan menggunakan pendekatan deskritif. Penelitian ini mengeksplorasi dan memotret situasi yang akan diteliti secara luas dan mendalam khususnya mengenai faktor-faktor yang mempengaruhi perhitungan pajak penghasilan pasal 29 di perusahaan pembiayaan pada PT.Hasjrat Multifinance Manado.

Tempat dan Waktu Penelitian. Berdasarkan permasalahan di atas, maka penelitian di dilakukan di PT. Hasjrat Multifinance Manado di Jalan Sudirman no.119 A,Manado 95122.Waktu penelitian April 2018 sampai dengan selesai.

Jenis data Penelitian. Data adalah kesimplan informasi yang diperlukan untuk pengambilan keputusan (Kuncoro 2002:124). Penelitian ini menggunakan jenis data kualitatif dan kuantitatif.

1. Data Kualitatif. Data kualitatif dalam penelitian ini berisi hasil wawancara tentang factor-faktor apa saja yang mempengaruhi perhitungan PPh pasal 29 pada PT. Hasjrat Multifinance Manado.

2. Data Kuantitatif. Data kuantitatif dalam penelitian ini merupakan hasil dokumentasi berupa sejarah perusahaan, struktur organisasi perusahaan, jenis dan skema pembiayaan, serta data keuangan seperti laporan keuangan perusahaan dan SPT masa tahun 2017.

Sumber Data Penelitian. Sumber data dalam penelitian ini yaitu menggunakan data primer dimana data yang diperoleh melalui sumber-sumber asli yang berasal dari PT.Hasjrat Multifinance Manado melalui wawancara secara langsung dan dokumentasi untuk mendapatkan data-data yang relevan dengan penelitian ini.

Metode Pengumpulan Data. Metode pengumpulan data yang digunakan dalam penelitian ini yaitu berupa :

a. Wawancara (interview). Menurut Jogiyanto (2013:114) wawancara (interview) adalah komunikasi dua arah untuk mendapatkan data dari responden, wawancara bertujuan untuk mendapatkan informasi secara lebih terperinci yang berhubungan dengan penelitian. Proses memperoleh keterangan untuk tujuan penelitian dengan cara tanya jawab dengan menatap muka antara penanya dan pewawancara dengan seorang penjawab, dalam hal ini pada bagian Accounting, bagian umum dan seksi perpajakan PT. Hasjrat Multifinance dengan pertanyaan-pertanyaan sebagai berikut: (1) gambaran umum dan sejarah perusahaan; (2) penetapan target dan realisasi pembiayaan; (3) bidang usaha Pembiayaan konsumen; dan (4) faktor- faktor yang mempengaruhi perhitungan PPh Badan.

b. Dokumentasi. Dokumentasi adalah penelitian yang dilakukan dengan cara mengumpulkan dokument-dokumen yang berhubungan dengan pajak penghasilan pasal 29/badan berupa SPT masa tahunan 2017 dan laporan keuangan tahun 2017 PT.Hasjrat Multifinance Manado.

Metode dan proses analisis. Berdasarkan masalah dan teknik pengumpulan data, penulis menggunakan metode deskriptif dengan tujuan membandingkan, menguraikan memberikan gambaran perusahaan dan menerangkan suatu data yang kemudian dianalisis, sehingga dapat membuat suatu kesimpulan sesuai dengan informasi dan data yang telah dikumpulkan. Proses analisis yang akan digunakan yaitu:

1. Tahap pertama, peneliti akan mengumpulkan data dari PT.Hasjrat Multifinance sebagai langka awal untuk mengetahui keadaan perusahaan terutama mengenai faktor-faktor yang mempengaruhi perhitungan Pajak penghasil pasal 29/badan. Data akan diambil dengan cara melakukan wawancara dan mendokumentasikan data-data yang diperlukan dalam penelitian ini. 
2. Tahap kedua, peneliti akan membahas data-data yang telah dikumpulkan serta menghitung PPh pasal 29/badan PT.Hasjrat Multifinance dengan menggunakan tarif pajak sesuai undang-undang PPh pasal 29/badan yang berlaku. Selanjutnya, peneliti merekapitulasi data waktu penyetoran dan pelaporan PPhpasal 29/badan PT.Hasjrat Multifinance untuk mengetahui ketepatan waktu dalam hal penyetoran dan pelaporan PPh pasal 29/badan.

3. Tahap ketiga, setelah mengolah data peneliti akan menganalisa perbandingan penghitungan PPh pasal 29 menurut PT.Hasjrat Mulifinance dengan perhitungan PPh pasal 29 menurut undang-undang yang berlaku. Selanjutnya, peneliti menganalisa apakah PT.Hasjrat Multifinance ada keterlambatan dalam penyetoran dan pelaporan $\mathrm{PPh}$ pasal 25.

4. Tahap keempat, penulis menarik kesimpulan dari bahasan dan perbandingan yang telah dilakukan dalam tahap-tahap sebelumnya.

5. Tahap terakhir yang dilakukan yaitu memberikan saran jika ditemukansuatu yang diperbaiki oleh perusahaan, agar jadi lebih baik.

\section{HASIL PENELITIAN DAN PEMBAHASAN}

4.1. Gambaran Umum Obyek Penelitian

PT. Hasjrat Multifinance adalah perusahaan yang bergarak dalam bidang pembiayaan konsumen. Perusahan ini berdiri pada tanggal 07 September 1990 berdasarkan akte notaris no 7 yang di buat oleh Notaris Rosmanus Harmaka Hardaseputra,SH yang berkedudukan di Manado, pada saat itu nama perusahaan ini adalah PT.HASJRAT FINANCE COMPANY.Selanjutnya pada tanggal 23 November 1990, perusahan melakukan perubahan nama menjadi PT.Hasjrat Multifinance. Perusahaan ini didirikan untuk jangka waktu tujuh puluh lima tahun lamanya, dan mulai berjalan pada saat perseroan ini menjadi badan hukum. Pada saat didirikan perusahaan ini bermaksud dan bertujuan menjalanakan usaha pembiayaan berupa:

a. Sewa Guna Usaha (Leasing Company) yaitu badan usaha yang melakukan kegiatan pembiayaan dalam bentuk penyediaan barang modal.

b. Menjalankan Perusahaan pembiayaan Konsumen (Consumer Finance Company), yaitu sebagai badan usaha yang melakukan kegiatan pembiayaan untuk pengadaan barang berdasarkan kebutuhan konsumen dengan sistem pembayaran angsur atau berkala oleh konsumen, dalam bentuk penyediaan dana bagi konsumen untuk pembelian barang yang pembayarannya dilakukan secara angsuran atau berkala oleh konsumen.

c. Menjalankan Perusahaan Modal Ventura (Ventura Capital Company) yaitu sebagai badan usaha yang melakukan kegiatan pembiayaan dalam bentuk pernyataan modal ke dalam suatu perusahaan pasangan usaha (Investee Company) untuk jangka waktu tertentu.

d. Menjalankan perusahaan anjak piutang ( Factoring company) yaitu sebagai badan usaha yang melakukan kegiatan pembiayaan dalam bentuk pembelian dan atau engalihan serta pengurusan piutang atau tagihan jangka pendek suatu perusahaa dari transaksi perdagangan dalam atau luar negeri.

Perusahaan ini mempunyai modal dasar pada waktu itu sebesar Rp.20.000.000.000,(Dua puluh milyar rupiah) yang terdiri dari 20.000.000 (dua puluh juta) saham, tiap-tiap saham bernilai pokok nominal Rp. 1.000,-(seribu rupiah). Dari jumlah modal dasar tersebut telah di tempat atau di keluarkan oleh prseroan dan wajib di setor penuh dengan uang tunai dalam kas oleh pemegang saham sebesar 5.000.000 (lima juta) lembar saham atau Rp. 5.000.000.000,- (Lima milyar rupiah). Kegiatan usaha perusahaan ini di mulai pada tanggal 25 Januari tahun 1995, dengan memperoleh izin usaha sebagai perusahaan pembiayaan dari Menteri keuangan sebagai perusahaan yang dapat melakukan kegiatan dalam bidang sewa guna usaha, anjak piutang, usaha kartu kredit dan Pembiayaan Konsumen. Dan pada saat ini, 
Perusahaan bergerak dalam bidang pembiayaan konsumen. Seiring waktu dan perkembangan serta kemajuan perusahaan, maka sesuai Peraturan Otoritas Jasa Keuanag(POJK) No.29/POJK-05/2014 tentang penyelenggaraan Usaha Perusahaan Pembiayaan dimana salah satunya mengatur perubahan kegiatan usaha yang wajib bagi paraperusahaan pembiayaan, sehingga untuk selanjutnya kegiatan usaha perusahaan adalah: (1) pembiayaan investasi; (2) pembiayaan modal kerja; (3) pembiayaan multiguna; dan (4) pembiayaan lainnya berdasarkan persetujuan OJK.

PT. Hasjrat Multifinance juga mengikuti dan menyesuaikan ketentuan- ketentuan Otoritas Jasa Keuangan tersebut, termasuk penyesuaian modal dasar dan modal yang di tempatkan. Untuk modal dasar menjadi Rp. 500.000.000.000,- (lima ratus milyar) serta modal yang di tempatkan menjadi Rp. 150.000.000.000,-(seratus lima puluh milyar). Selang jangka waktu sampai dengan sekarang ini pengurus perusahaan sudah mengalami perubahan,adapun susunan pengurus dalam sampai sekarang ini adalah:

1. Susunan Komisaris : (a) Komisaris Utama; (b) Komisaris; dan (c) Komisaris independen.

2. Susunan Direksi : (a) Direktur utama; dan (b) Direktur.

\section{Struktur Organisasi Perusahaan PT.Hasjrat Multifinance}

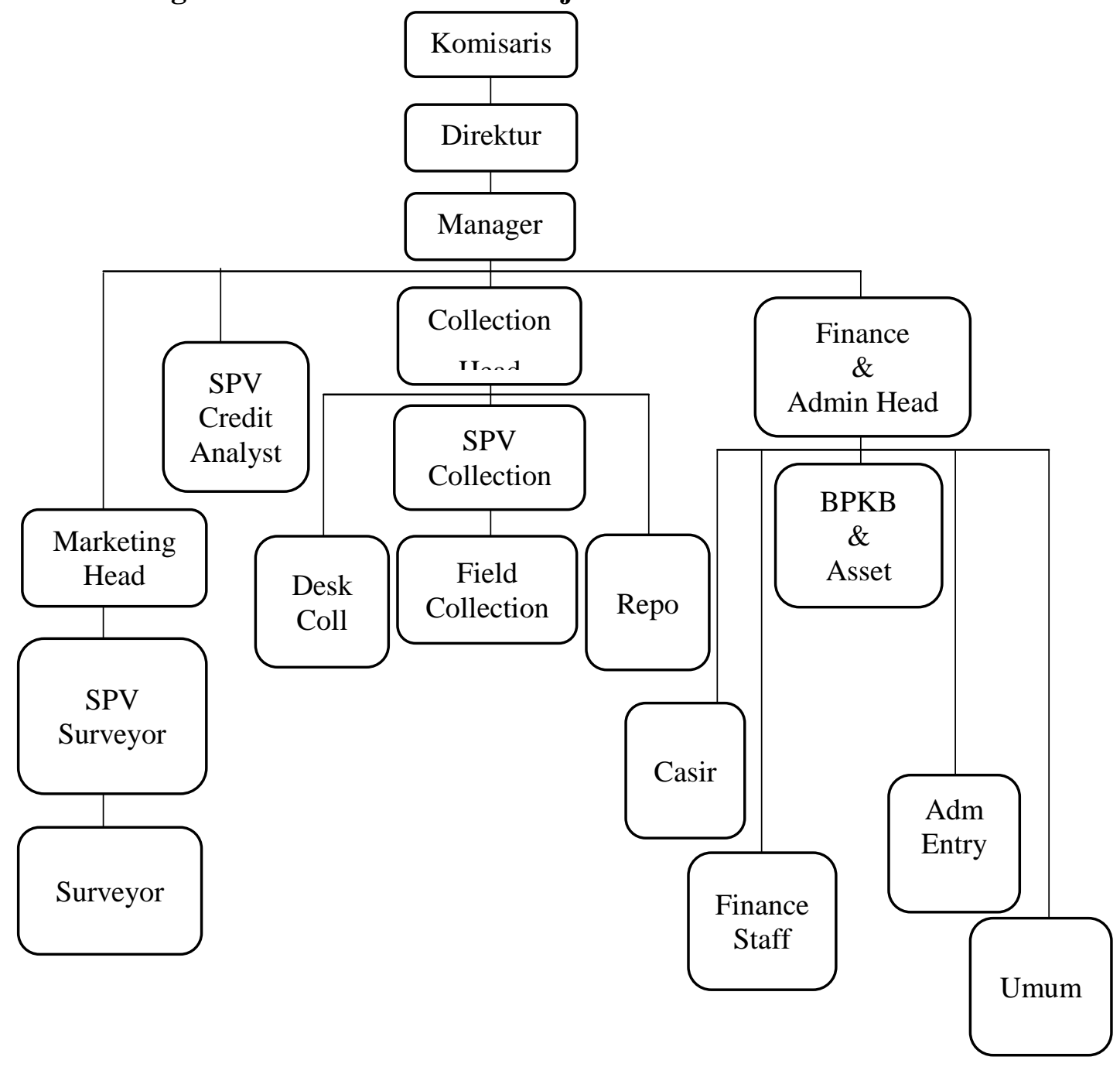

Tugas pokok dan tanggung jawab dalam masing-masing bagian sesuai struktur, dapat di jelaskan sebagai berikut :

1. Komisaris 
Komisaris adalah bagian yang terlibat untuk mengawasi jalannya perusahaan, baik dari dalam maupun dari luar perusahaan.

2. Direktur

Wewenang dan tanggung jawab direktur dapat diuraikan sebagai berikut :

a. Memimpin dan mengkoordinir semua kegiatan.

b. Menentukan kebijakan perusahaan terutama dalam bidang pembiayaan.

c. Mengangkat dan memberhentikan pegawai.

3. Manager

a. Memastikan pencapaian target pembiayaan dengan kualitas piutang yang baik (accounting receivable).

b. Bertanggung jawab atas penanganan piutang.

c. Memastikan atas kecukupan dan kuliatas tenga kerja.

d. Memastikan kualitas pelayanan yang baik terhadap konsumen dan hubungan baik dengan dealer.

4. Marketing Head (Kepala Pemasaran)

a. Memastikan pencapaian target pembiayaan dengan kualitas survey yang baik.

b. Memastikan proses pengajuan pembiayaan sesuai dengan prosedur.

c. Monitorring atas kinerja Team Marketing.

d. Membina hubungan baik dengan Dealer \& memantau competitor perusahaan.

5. Surveyor Coordinator (Koordinator Survei)

a. Bertanggung jawab atas kinerja dari seluruh surveyor

b. Memastikan seluruh permohonan pembiayaan dicatat dalam Book dan dilakukan survey semestinya.

c. Bertanggung jawab atas kualitas kredit yang disetujui atas dasar Survey report team surveyor

d. Memastikan Survey sampling dilakukan berkala

6. Surveyor

a. Melakukan survey \& foto tempat calon konsumen

b. Verifikasi informasi/data calon konsumen

c. Cek validitas \& foto dokumen kredit

d. Menjaga kuantitas \& kualitas kredit

7. Credit Analyst (Analisis Kredit)

a. Memastikan seluruh permohonan pembiayaan dicatat di Log Book

b. Bertanggung jawab proses screening atas kelengkapan dan keabsahan dokumen persyaratan

c. Bertanggung jawab melakukan verifikasi \& analisa kelayakan permohonan pembiayaan

d. Memastikan survey sampling dilakukan berkala

e. Bertanggung jawab menjaga kualitas kredit

8. Collection Head (Kepala Penagihan)

a. Bertanggung jawab atas pengelolaan Accounting Receivable

b. Memastikan pencapaian target pengelolaan \& penyelesaian Accounting Receivable

c. Memastikan penanganan piutang \& proses penarikan kendaraan

d. Melakukan review laporan collection

9. SPV Collector (Kolektor SPV)

a. Bertanggung jawab atas Kinerja dari seluruh Field Collector

b. Bertanggung jawab membuat rencana dan strategi harian penanganan piutang yaitu: (1) membuat daftar tagihan untuk setiap Field Collector; dan (2) melakukan pemetaan atas lokasi pembagian Collection.

10. Desk Coll (Meja Kerja) 

a. Memastikan setiap hari kerja melakukan penagihan melalui telepon atas
b. Bertanggung jawab membuat laporan lengkap aktivitas deskcoll
c. Bertanggung jawab untuk menindakkanjuti janji bayar konsumen

11. Field Collector (Kolektor Lapangan)

a. Bertanggung jawab atas penagihan angsuran tertunggak ke konsumen sesuai daftar tagihan di sistem dan Proforma rencana kunjungan

b. Bertanggung jawab membuat laporan hasi kunjungan harian penagihan ke konsumen

12. Report (Melaporkan)

a. Bertanggung jawab membuat strategi penanganan penarikan kendaraan (61 hari)

b. Bertanggung jawab melakukan penarikan kendaraan sesuai ketentuan

13. Finance \& Administration Head
a. Bertanggung jawab atas proses Keuangan \& Administrasi Cabang (termasuk rekonsiliasi kas besar \& kas kecil)
b. Bertanggung jawab atas pengelolaan BPKP
c. Bertanggung jawab atas proses Asuransi \& Fidusia
d. Bertanggung jawab atas asset di cabang

14. BPKB \& Asset
a. Bertanggung jawab atas control \& monitoring BPKB
b. Bertanggung jawab atas inventaris/penyimpanan Kendaraan Tarikan Cabang

15. Cashier (Kasir)
a. Bertanggung jawab atas penerimaan pembayaran angsuran dan non angsuran dari konsumen
b. Melakukan input data penerimaan angsuran di sistem
c. Bertanggung jawab atas laporan penerimaan uang

16. Finance Staff (Staf Keuangan)
a. Melakukan Monitoring kuintansi pembayaran
b. Melakukan proses pengajuan pelunasan Angsuran (ET) konsumen
c. Melakukan rekonsiliasi
d. Membuat laporan keuangan

17. Admin Entry (Admin Masuk)
a. Melakukan penginputan data calon konsumen di sistem
b. Melakukan pencetakan dokumen-dokumen kredit
c. Penyimpanan (filling) \& pengadministrasian dokumen kredit

18. Umum
a. Mempersiapkan dokumen kredit yang akan di tanda tangani
b. Menangani klaim asuransi konsumen
c. Melakukan fungsi HRD

\section{Visi dan Misi Perusahaan}

PT.Hasjrat Multifinance adalah perusahaan pembiayaan yang dinamis dengan membiayai berbagai produk antara lain, Mobil Toyota, Motor Yamaha, Motor tempel Yamaha, Mesin Pertanian Yanmar dan lain-lain. Ada pun Visi dan Misi perusahaan adalah :

VISI : Menjadi perusahaan pembiayaan yang terdepan di Indonesia, dengan pelayaan yang terbaik.

MISI :

- Melakukan aktivitas bisnis secara transparan dan dapat di pertanggung jawabkan.

- Meningkatkan hubungan baik dan saling percaya dengan principal, karyawan, dealer dan supplier.

- Menciptakan kepuasan pelanggan/customer melalui layanan pembiayaan yang terbaik.

- Melakukan perluasan dan pengembangan bisnis 
- Menghargai kemampuan individu tampa mengabaikan kerja sama tim.

- Selalu berkontribusi untuk perkembangan ekonomi dan social.

\subsection{Hasil Penelitian}

Kegiatan Usaha PT. Hasjrat Multifinance. Kegiatan Usaha PT.Hasjrat Multifinance adalah pembiayaan konsumen, kegiatan tersebut dilaksanakan melalui penyaluran dana ke konsumen dengan pembiayaan Multiguna yang terdiri atas atas :

- Pembiayaan multiguna mobil Toyota

- Pembiayaan multiguna sepeda motor Yamaha

- Pembiayaan multiguna mesin kapal/motor tempel

- Pembiayaan multiguna mesin pertanian yanmar

- Pembiayaan multiguna rumah dan apartemen.

Syarat Pembiayaan Konsumen. Bagi calon konsumen/Custor, syarat untuk permohonan mendapatkan fasilitas pembiayaan meliputi :

a. Perorangan :

- Foto copy KTP pemohon dan istri/suami/penjamin

- Foto copy kartu keluarga

- Surat keterangan penghasilan/slip gaji

- Foto copy buku tabungan 3 bulan terakhir

- Foto copy rekening PBB/Telpon/Listrik (salah satu)

- Surat keterangan usaha

- Foto copy izin trayek (angkutan umum)

- Foto copy NPWP

b. Usaha perorangan

- Foto copy KTP pemohon dan istri/suami/penjamin

- Foto copy kartu keluarga

- Foto copy buku tabungan 3 bulan terakhir

- Foto copy rekening PBB/Telpon/Listrik (salah satu)

- Surat keterangan usaha

- Foto copy izin trayek (angkutan umum)

- Foto copy rekening koran 3 bulan terakhir

- Foto copy NPWP

c. Profesi

- Foto copy KTP pemohon dan istri/suami/penjamin

- Foto copy kartu keluarga

- Foto copy buku tabungan 3 bulan terakhir

- Foto copy rekening PBB/Telpon/Listrik (salah satu)

- Surat keterangan usaha

- Foto copy izin praktek

- Foto copy izin trayek (angkutan umum)

- Foto copy NPWP

d. Badan hukum

- Foto copy KTP Direktur, Komisaris dan atau yang di kuasakan

- Foto copy izin trayek (angkutan)

- Foto copy Akte pendirian dan perubahan

- Foto copy TDP

- Foto copy NPWP

- Surat keterangan usaha

- Surat kuasa komisaris

- Foto copy surat pengesahan kehakiman 
- Surat perintah kerja (untuk kontraktor).

Proses Pembiayaan Konsumen. Pembiayaan konsumen yang di berikan oleh PT.Hasjrat Multifinance adalah pembiayaan kendaraan bermotor yaitu menyediakan dana untuk membiayai pemohon/calon konsumen dalam pengadaan/pembelian kendaraan bermotor melalui Dealer/Showroom dengan system pembayaran angsuran yang di bayarkan perbulan oleh konsumen berdasarkan Perjanjian Pembiayaan Konsumen dalam jangka waktu tertentu. Ada pun proses Pembiayaan Konsumen sebagai berikut :

- $\quad$ Sales Dealer

Sales marketing dealer memberikan order pengajuan aplikasi pembiayaan konsumen ke surveyor.

- Surveyor (perusahan pembiayaan)

Menerima order pengajuan aplikasi dan serta memeriksa kelengkapan dokument persyaratan pembiayaan dan menginformasikan order pembiayaan ke Supervisor (SPV) Surveyor.

- $\quad$ Supervysor Surveyor (SPV)

Menerima order pengajuan aplikasi pembiayaan konsumen dari Surveyor serta melakukan proses cek black list di system.

- $\quad$ Administrasi kredit

Menerima informasi order pembiayaan berupa data calon konsumen dari SPV Surveyor untuk di input di system.

- Surveyor

Menerima informasi order dan melakukan proses survey ke rumah konsumen serta melakukan cek lingkungan sekitar temapt tinggal konsumen. Hasil survey di laporkan kembali ke SPV Surveyor.

- Supervysor Surveyor

Selanjutnya SPV Supervysor menerima pengajuan pembiayaan dari surveyor utuk memeriksa hasil survey serta menyerahkan kembali ke Adminitrasi kredit.

- Administrasi Kredit

Menerima pengajuan pembiayaan konsumen dari SPV Surveyor dan melakukan pengimputan data konsumen dan permohonan pembiayaan konsumen ke dalam system. Administrasi kredit menyerahkan pengajuan pembiayaan konsumen ke Crdit Analyst (CA).

- $\quad$ Credit Analyst (CA)

Menerima pengajuan pembiayaan konsumen dari Administrasi kredit untuk melakukan pemeriksaaan document-dokumnet persyaratan kredit sesuai ketentuan yang berlaku, melakukan validasi (cross cek kebenaran dan kesamaa) informasi yang tercantum di form permohonan pembiayaan dan lembar hasil survey dengan document persyaratan kredit yang di berikan oleh calon konsumen. Credit Analyst juga melakukan verifikasi telepon ulang ke calon konsumen, dari hasil verifikasi telpon ini akan di bandingkan dengan document persyratan kredit dan pada akhirnya Credit Analyst ini memberikan rekomendasi kepada apakah permohoanna pembiayaan ini di setujui atau di tolok kepada Marketing Head (MH). Selanjutnya Credit Analyst menyerahkan berkan pengajuan pembiayaan beserta document-dokumnet persyaratan kredit ke Marketing Head.

- Marketing Head (MH)

Marketing Head menerima pengajuan pembiayaan beserta document-dokumnet pendukung persyaratan kredit dari Credit Analyst untuk mereview hasil rekomendasi permohonan pembiayaan dari credit Analyst dan melakukan proses persetujuan kredit (approval credit) di system.

- Administrasi kredit 
Malakukan cetak/print document kontrak pembiayaan konsumen dari system berupa :

- Perjanjian Konsumen

- Surat kuasa fiducia

- Surat pernyataan

- Surat kuasa

- Surat pernyataan jaminan

- Surat pernyataan bersama

- Surat persetujuan suami istri

- Surat penyerahan fisik

- Kwitansi

- Berita Acara Serah Terima

- Surat pernyataan debitur

- Form penutupan asuransi

dan menyerahkan document kontrak pembiayaan ini ke Administrasi umum.

- Administrasi Umum

Menerima document kontrak pembiayaan dari Administrasi kredit untuk dilakukan proses penandatanganan oleh pemohon.

- Kuasa Direksi

Melakukan tanda tangan document-dokumnet kontrak pembiayaan konsumen yang sebelumnya ditanda tangani oleh konsument.

- Dealer

Dealer akan mengeluarkan DO/Faktur berdasarkan kontrak perjanjian pembiayaan konsument, dan konsumen akan segera menerima kendaraan atau barang.

- $\quad$ Administrasi Umum

Melakukan filing/penyimpanan dokumnet-dokumnet kontrak pembiayaan konsument sesuai dengan urutan nomor kontrak dan tanggal.

Prosedur Pembayaran Angsuran. Untuk mempermudah konsumen melakukan pembayaran angsuran dan untuk mengurangi resiko apabila konsumen datang membayar konsumen di kasir dalam bentuk tunai, maka setiap konsumen akan diberikan nomor khusus dari bank yang disesuaikan dengan nomor kontrak perjanjian yang disebut virtual account. Konsumen akan menyetor angsuran ke bank dengan menggunakan nomor virtual account tersebut. Untuk sistem ini PT.Hasjrat Multifinance diberikan akses untuk melihat rekening koran bank dan melakukan pencatatkan atas pembayaran angsuran konsumen tersebut, sehingga saldo piutang konsumen akan langsung berkurang. Bank yang akan berkerja sama dengaan PT.Hasjrat Multifinance dalam hal virtual account adalah Bank Raya Indonesia (BRI) dan Bank Danamon Indonesia.

Prosedur Penagihan Angsuran. Prosedur penagihan angsuran dilakukan dengan beberapa tahapan :

- Layanan pesan singkat ( Shart Massager Service Blast-SMS Blast)

Tahapan ini adalah pesan yang disampaikan ke konsumen untuk mengingatkan konsumen melakukan pembayaran angsuran sesuai jatuh tempo. Pesan singkat ini disampaikan untuk jatuh tempo 1 (satu) hari sebelum jatuh tempo sampai dengan 1 (satu) hari sesudah jatuh tempo pembayaran angsuran

- Penyampainan melalui telepon (Desk Coll)

Tahapan ini di sampaikan melalui telepon untuk mengingatkan konsumen agar segera melakukan pembayaran angsuran. Tahapan ini melakukan konsumen yang mengungat 2 (dua) sampai 7 (tujuh) hari.

- Tagih

Tahapan ini melakukan pembayaran walaupun sudah dilakukan pemberitahuan melalui telepon. Petugas penagihan akan menagih dengan membawak kwintasi tagiha. Tahapan ini 
dilakukan konsumen yang sudah mengungah 8 (delapan) hari sampai dengan 30 (tiga puluh) hari. Dalam tahapan ini juga ada ditebirtkan surat pemberitahuan gungatan, surat pemberitahuan ini akan diberikan dalam 3 (tiga) kali sampai dengan penerbitkan surat perintah penarikan kendaraan / barang jaminan.

\subsection{Pembahasan}

\section{Faktor-faktor yang mempengaruhi perhitungan PPh 29}

Faktor Kontribusi Penjualan Dealer. Penjualan delaer sangat mempengaruhi jumlah pembiayaan,kontribusi yang diberikan dealer merupakan sumber pembiayaan utama PT. Hasjrat Multifinance, penjualan dealer ini mencakup penjualan secara tunai, penjualan secara kredit dan penjualan melalui instansi. Dealer dalam hal ini adalah PT. Hasjrat Abadi, PT. Samudra Puranabile Abdi, dan CV. Auto Nusa Abadi. Pembiayaan PT. Hasjrat Multifinance di ambil dari jumlah penjualan kredit dari dealer. Untuk penjualan kredit dengan melalui pembiayaan PT. Hasjrat Multifinance untuk tahun 2017 terdiri atas pebiayaan mobil 3.647 unit atau 53.12\% dari jumlah total penjualan secara kredit mobil oleh dealer, dengan nilai pembiayaan Rp. 663.702.124.650,-. Untuk pembiayaan sepeda motor mencapai 14.130 unit atau $36.84 \%$ dari jumlah penjualan kredit dealer, dengan nilai pembiayaan sebesar Rp. 248.666.860.350,-Total dana yang telah di salurkan untuk pembiayaan melalui kontibusi dealer tahun 2017 sebesar Rp.912.368.985.000,-,nilai pembiayaan ini mengalimi penurunan bila di bandingkan dengan tahun sebelumnya. Pembiayaan tahun 2016 Rp. 1.049.430.000.000,- atau hanya mencapai 87\% bila di bandingkan dengan pembiayaan tahun lalu. Akan tetapi jika dibandingkan dengan pembiayaan tahun-tahun sebelumnya (2013-2105) pembiayaan mengalimi perkembangan yang baik. Perbandingan perkembaan pembiayaan dapat dilihat pada Tabel 1.

Tabel 1. Pembiayaan tahun 2013-2017 (dalam jutaan)

\begin{tabular}{|c|c|c|c|c|c|c|c|c|c|}
\hline Produk & 2013 & 2014 & $\%$ & 2015 & $\%$ & 2016 & $\%$ & 2017 & $\%$ \\
\hline MOBIL & 372.457 & 431.557 & 115,9 & 597.438 & 138,4 & 730.010 & 122,2 & 663.702 & 91 \\
\hline SPM & 127.067 & 214.486 & 168,8 & 51.279 & 23,9 & 319.420 & 622,9 & 248.667 & 78 \\
\hline TOTAL & 499.524 & 646.043 & 129,3 & 648.717 & 100,4 & 1.049 .430 & 161,8 & 912.369 & 87 \\
\hline
\end{tabular}

Faktor Bunga Pembiayaan. Tingkat suku bunga ditetapkan oleh manajemen dengan mempertimbangkan keadaan pasar dan kompotitor/persaingan dan dapat berubah sewaktuwaktu. Bunga yang ditawarkan adalah bunga flat atau bunga tetap yang di konfersi ke bunga efektif ke dalam sistem. Pada akhir Tahun 2017 bunga yang ditetapkan dapat di lihat pada Tabel 2.

Tabel 2. Rata-rata bunga pembiayaan

\begin{tabular}{lcrrrrr}
\hline \multirow{2}{*}{ Type } & \multirow{2}{*}{ UM } & \multicolumn{5}{c}{ Bunga } \\
\cline { 3 - 7 } & $20 \%$ & $\mathbf{1 2}$ bln & $\mathbf{2 4}$ bln & $\mathbf{3 6}$ bln & $\mathbf{4 8}$ bln & $\mathbf{6 0}$ bln \\
\hline Avansa, NAV & $20 \%$ & $6,90 \%$ & $6,56 \%$ & $6,70 \%$ & $7,12 \%$ & $7,88 \%$ \\
Rush, Innova, Yaris,Vios, Camry & $6,48 \%$ & $6,60 \%$ & $6,95 \%$ & $7,65 \%$ \\
Sienta, Fortuner & $20 \%$ & $6,75 \%$ & $6,45 \%$ & $6,60 \%$ & $6,92 \%$ & $7,61 \%$ \\
Agya & $20 \%$ & $7,11 \%$ & $6,72 \%$ & $6,91 \%$ & $7,38 \%$ & $8,22 \%$ \\
Calya & $20 \%$ & $6,99 \%$ & $6,62 \%$ & $6,81 \%$ & $7,23 \%$ & $8,15 \%$ \\
Etios & $20 \%$ & $6,89 \%$ & $6,55 \%$ & $6,72 \%$ & $7,14 \%$ & $7,89 \%$ \\
Hilux S-CAB & $20 \%$ & $8,00 \%$ & $7,52 \%$ & $7,78 \%$ & $8,44 \%$ & \\
Hilux D-CAB & $20 \%$ & $6,80 \%$ & $6,44 \%$ & $6,63 \%$ & $7,08 \%$ & \\
& & & & & & \\
Sepeda Motor Yamaha & $25 \%$ & $23,20 \%$ & $21,50 \%$ & $23,20 \%$ & $23,20 \%$ & $23,20 \%$ \\
\hline
\end{tabular}


Faktor Biaya Administrasi. Biaya adminstrasi adalah biaya yang dibebankan kepada konsumen untuk setiap kontrak perjanjian. Biaya administrasi ini menjadi pendapatan perusahaan Pembiayaan administrasi ini terdiri atas :

Mobil kontrak 1 (satu) tahun sebesar

Rp. 2.400 .000

Mobil kontrak 2 (dua) tahun sebesar

Rp. 2.500 .000

Mobil kontrak 3 (tiga) tahun sebesar

Rp. 2.600 .000

Mobil kontrak 4 (empat) tahun sebesar

Rp. 2.700 .000

Mobil kontrak 5 (lima) tahun sebesar

Rp. 2.800 .000

Motor kontrak 12 (dua belas) bulan sebesar

Rp. $\quad 400.000$

Motor kontrak 18 (delapan belas) bulan sebesar

Rp. $\quad 450.000$

Motor kontrak 24 (dua pluh empa) bulan sebesar

Rp. $\quad 500.000$

Motor kontrak 30 (tiga puluh) bulan sebesar

Rp. 575.000

Motor kontrak 36 (tiga puluh enam) bulan sebesar

Rp. 650.000

Perhitungan PPh badan. Perhitungan PPh badan berdasarkan laporan keuangan yang merupakan hasil akhir aktivitas perusahaan dalam suatu periode akuntansi yang terdiri atas posisi neraca dan laba rugi. Laporan keuangan ini juga dibuat untuk memberikan gambaran mengenai aktivitas operasional perusahaan yang memudahkan bagi pihak-pihak yang berpentingan baik internal maupun eksternal untuk mengevaluasikegiatan perusahaan. Laporan keuangan ini akan dilaporkan ke Otoritas Jasa Keuangan dank e media masa sesudah di audit oleh kantor akuntan public. Dalam laporan keuangan ini untuk mendapatkan nilai laba sebelumpajak penghasilan sebelumnya dilakukan penyesuaian untuk medapatkan penghasilan kena pajak. Penyesuaian ini adalah koreksi fiskal, koreksi fiscal ini terdiri atas koreksifiskal positif dan koreksi negatif. Koreksi fiskal ini di maksudkan agar laporan komersial dengan laporan fiskal dapat di sesuaikan untuk menghitung besarnya pajak penghasilan. PT.Hasjrat Multifinance melakukan koreksi fiskal negatif untuk rekening Pendapatan jasa giro, pendapatan bunga deposito, Iuran Pensiun. Untuk koreksi fiskal positif adalah biaya sumbangan, biaya penyusutan Tax Amnesti, denda Pajak. Penelitian akan dilakukan pada laporan laba rugi komersial yang dibuat oleh PT.Hasjrat Multifinance berdasarkan akuntansi. Berikut ini yang akan difokus penelitian dalam rangka perhitungan PPh badan pada PT.Hasjrat Multifinance adalah laporan laba rugi periode 1 Januari - 31 Desember 2017. Perhitungan besarnya PPh badan dapat di lihat pada table 4.7 


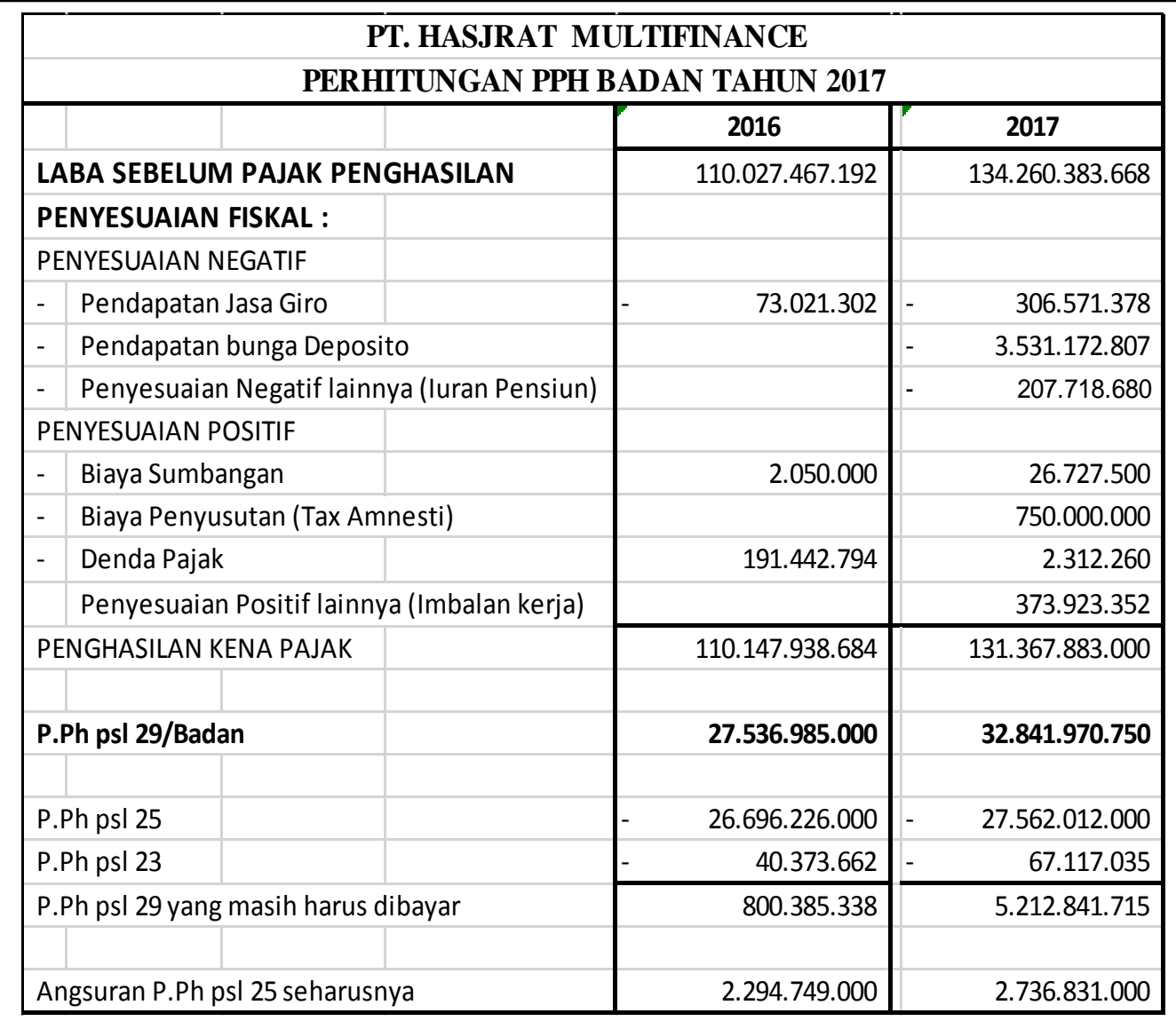

\section{KESIMPULAN DAN SARAN}

\subsection{Kesimpulan}

Berdasarkan hasil penelitian yang telah dikemukakan diatas, maka dapat diambil kesimpulan bahwa PPh Badan di pengaruhi oleh :

1. Penjualan Dealer, semakin besar penjualan dealer secara kredit maka semakin besar kontribusi pembiayaan pada perusahaan pembiayaan yang pada akhirnya meningkatkan penghasilan dan akan meningkatkan pula $\mathrm{PPh}$ terutang dalam hal ini PPh badan.

2. Bunga angsuran adalah penerimaan utama PT.Hasjrat Multifinance. Besarnya kontribusi penjualan kredit akan berkaitan dengan nilai penerimaan bunga angsuran.Perhitungan nilai bunga angsuran berdasarkan sisa pokok hutang ditambah nilai asuransi yang dibayar secara angsur oleh konsumen.

3. Sisa pokok hutang di tambah pembebanan asuransi yang dibayarkan konsumen adalah merupakan nilai pembiayaan. Nilai pembiayaan ini di tambahkan dengan nilai bunga, merupakan Nilai Kontrak perjanjian.

\subsection{Saran}

Berdasarkan hasil penelitian di PT.Hasjrat Multifinance, maka peneliti memberikan saran antara lain sebagai berikut:

1. Terus menciptakan hubungan baik dengan Dealer-delaer sebagai penjual kendaraan, serta mengikuti atau ikut serta setiap program-program promosi yang dilakukan oleh dealer.

2. Terus mempertahankan hubungan kerja yang baik, saling mendukung, serta toleransi dengan karyawan dalam hal ini Sales dan Counter Sales sebagai ujung tombak penjualan di dealer, yang adalah pemberi prospek pembiayaan kepada PT.Hasjrat Multifinance. 
3. Membina hubungan kerjasama yang baik denga karyawan surveyor yang mengsurvei dan memeberikan informasi tentang kelayakan konsumen untuk mendapatkan pembiayaan.

4. Untuk meningkatkan nilai pembiayaan maka di sarankan PT.Hasjrat Multifinance untuk dapat membuat program-program pembiayaan tersediri, dengan menawarkan beberapa keunggulan perusahaan dan dapat memeberikan hadiah-hadiah menarik dan melakukan promosi atau iklan baik di media sosial, radio-radio ataupun televisi.

\section{DAFTAR PUSTAKA}

Adriani P J A. 2007. Pajak menurut peraturan-peraturan umum. Mohammad Zain. Jakarta. Asosiasi Perusahaan Pembiayaan Indonesia. 2014. Training of Basic Certification Program Module,Pemahaman bisnis, kegiatan usaha perusahaan pembiayaan.

Awit M,Mienati S1. 2015. Faktor-faktor yang mempengaruhi tingkat kepatuhan pengusaha kena pajak badan pedagang pengecer. Skripsi Fakultas Ekonomi dan Bisnis Universitas Airlangga.

Brotodiharjo, R Santoso. 1993. Pengantar Ilmu Hukum Oajak. Bandung: PT.Eresco

Direktorat Penelitian Kebijakan dan Pengaturan. 2016. Buku UU Otoritas Jasa Keuangan.

Hardiansyah.2017.Analisis Perhitungan Pajak penghasilan Badan pada PT.Pelabuhan Indonesia IV (Pesero) Makassar. Sripsi Jurusan AKuntansi

Husain, A. 2018.Perusahaan pembiayaan dan perlindungan konsumen OJK Provinsi Sulawesi utara Gorontalo dan Maluku utara.

Ikatan Akuntansi Indonesia. 2009. PSAK Nomor 46tentang Akuntansi Pajak Penghasiln.

Kementerian Keuangan Repoblik Indonesia. Direktorat Jenderal Pajak. 2011. Persandingan Undang-Undang ketentuan umum dan tatacara perpajakan.

Kementerian Keuangan Repoblik Indonesia. Persandingan susunan dalam satu naskah Undang-Undang Pajak Penghasilan. Direktorat Jennderal Pajak. 2011

Kuncoro M, 2003. Metode kuantitatif : Teori dan Aplikasi untuk Bisnis dan Ekonmi, UPPAMP YPKN, Jogyakarta.

Lubis, I. 2015. Akuntansi Pajak Terapan.Yogyakarta: Penerbit Andi.

Makala Otoritas Jasa Keuangan. 2015. Sosialisasi peraturan OJK mengenai perusahaan pembiayaan. Bidang pengawasan Industri Keuangan Non-Bank Otoritas Jasa Keuangan.

Mardiasmo.2009. Perpajakan Edisi Revisi 2009. Yogyakarta: Penerbit Andi.

Mardiasmo, 2016. Perpajakan edisi terbaru 2016, Yogyaarat: Penerbit Andi

Natakharisma,V dan Sumadi, K. 2014. Analisa Tax Palnning dalam meningkatkan optimalisasi pembayaran pajak penghasilan pada.PT.Chidehafu. Skripsi Jurusan Akuntansi.

Otoritas Jasa Keuangan, 2016, Buku undang-undang Otoritas Jasa Keuangan dan regulasi edukasi dan perlindungan konsumen, Direktorat penelitian kebijakan dan pengaturan edukasi dan perlindungan konsumen.

Peraturan Menteri Keuangan 101/PMK.010/2016 Tentang penyesuaian besarnya Penghasilan Tidak Kena Pajak.

Pontoh W, 2013. Akuntansi konsep dan Aplikasi,Penerbit Halaman Muka Jakarta.

Prasetyono, D S. 2017. Buku Pinter Pajak. Penerbit Laksana

Resmi, Siti. 2008. Perpajakan Teori dan Kasus. Edisi 8 buku 1. Yogyakarta: Salemba empat. Santoso, B R. 1993. Pengantar ilmu hukum pajak. Bandung. Penerbit PT.Eesco.

Suandy, Erly. 2016. Perpajakan: Pembahasan PPh pasal 21 Sesuai PTKP tahun 2006. Jakarta: Penerbit Salemba Empay.

Supriyanto, E. 2011. Akuntansi Perpajakan. Edisi Pertama. Cetakan Pertama. Graha Ilmu. Yogyakarta. 
Szarowska, Irena. 2014. Personal Income Taxation in a Context of a Structure. Journal Elsevier.

Waluyo. 2011. Perpajakan Indonesia edisi 10.Penerbit Salemba Empat Jakarta.

Warren, Reeve dan Duchac. 2015. Accounting-Indonesia Adaptation, (Pengantar Akuntasi Adaptasi Indonesia) Edisi 25, Salemba 4 Jakarta.

Widyaningsih, A. 2011. Hukum Pajak dan perpajakan dengan pendekatan Mind Map.Bandung. Penerbit CV Alfabeta. 